of the sandstones. Both Dr. Dawson and Dr. Limmarsson therefore long ago expressed the opinion that the Bilobites of Sweden and America must have been trails of some animals. In order to explain this mode of occurrence so that it might not appear as proof against the vegetable nature of the bodies, Saporta takes refuge in a somewhat curious manner of fossilisation described and illustrated by woodcuts in the review referred to. As I feel sure that every one who has made himself acquainted with true modes of fossilisation will immediately be aware that the process adopted by Saporta is indeed most improbable, it will be superfluous to dwell any longer on that question. But even granted that the plants sometimes should occur in this way-which statement I, however, think must be due to some confusion as to the real facts-such an occurrence could never be regarded but as a very rare exception to the general rule. And it therefore does not explain why the Bilobites should only occur in this, for true plants, exceptional way, (on the under surfaces of the slabs), never as true fossils embedded in the rock. This mole of occurrence harmonises, on the other hand, perfectly with the view that the Bilobites are trails of some animals, while it cannot be expla'ned on the supposition that they are true organic bodies.

One arrives precisely at the same conclusions on studying their external structure, which posiesses pretty great analogies as well with the trails of Limulus, long ago described by Dawson, as with those of other Crustaceans, described by myself. It is true that Saporta lays great stress on some superfici al markings which are to be seen on some of the French specimens; but those who have studied not only the French Bilobites, but also those from Sweden or America, will soon be aware that the markings referred to are quite accidental. It is indeed surprising that Saporta, while adopting my views concerning Crossochorda, does not see that the Bilobites are somewhat analogous forms, though much larger. There is consequently $n^{\prime \prime}$ reason why they should be regarded as other than the trails of Crustaceans.

As for Eophyton, it is a pity that this should still be mentioned as possibly of organic origin. It occurs precisely as true trails on the under surface of the slabs; it is found in every system from the Cambrian to the present time, where it can stil be studied on the seashores; all the different forms, under which it presents itself are also still to be seen there. Althou sh it thus has been proved that it cannot be any organisw, Saporta still adheres to the opposite opinion. Now, if he had read through my work, he would have learnt that I by experiment have demonstrated that Eophyton can not only be produced by drifting plants, but also by the tentacles of Medusæ or other soft bodies. Now there are casts of Medusæ associated with. Cambrian Eophytons of Sweden, and their habits were probably--as I have elsewhere 1 tried to show-similar to those of the existing Polyclonia frondosa, which creeps on the mud by means of its tentacles, and it is therefore likely that the Cambrian Eophytons are of this origin.

It is further stated that "the Chondrites of the Flysch, strongly impregnated as they are with carbonaceous matter, are admitted on all hand ; to be Algx, and the author asks how the same origin can be denied to casts of specifically identical Chondrites of the Cretaceous and so on to the Liassic forms." This argument is, however, a real "petitio principii," for it is so far from the actual state of things that the Chondrites of the Flysch are on all hands admitted to be Algæ, that many duthors, and among them Dr. Th. Fuchs, of Vienna, whose excellent and exbaustive studies of the Flysch are everywhere known, hold a quite opposite opinion. And as for the supposed carbonaceous matter, it is not much better with this, as will be shown from a communication from Dr. Fuchs published in my work referred to : "The supposed carbonaceous nature of the Chondrites of the Flysch is in $\mathrm{ny}$ opinion a perfect mistake. They are certainly very often quite black, but even in such cases they consist only of dark marl, not of coal."

Much more might be said on the fossil Algæ, but as I am about to combat the views held by Saporta more fully in a special work, I will here only add that I have found no statement whatever in his work referred to which would tend to alter my opinion, that almost all the "Algae incerte sedis" in Schimper-Zittel's "Handbuch der Paleon'ologie" are not vegetable fossils.

A. G. NATHORST

Stockholm, April 9

' A. G. Nathorst, "Om aftryck af Medusar i Sveriges Kambriska layer." (Svenska Vetenshaps Akademiens Handlinger, Bd. xix. No. $x$, Stockholm; Norsted och Söner, 1881.)
DR. NATHORST has certainly shown that many of the markings referred to Algæ by some authors might be tracks left by moving animals on a soft mud, but is there reason to suppose that there are conditions under which submarine surfaces of very soft mud with minute tracks have, or could ever have been preserved. On the otber hand there is no question about seaweed having existed in Palæozoic and Mesozoic times, and either some of the markings in question are their prints, or no traces of them are preserved. Now it is an uncontroverted fact that even the most indestructible of all vegetable tissue, that of the Coniferæ, has been met with in the same condition of fossilisation, i.e a projecting cast in sandstone on the under side of a slab, and without any internal trace of tissue or even of colouring due to carbon or iron, and Sapnrta has offered a satisfactory explanation of the origin of such casts. From the relative rarity with which terrestrial plants have been thus preserved, Nathorst almost derides Saporta's application of this explanation to fossil Alyæ, yet it is by no means improbable that this may be their normal mode of preservation. The decay of dead olive-green seaweeds in water must be very rapid. The decomposition of some among them sets in almost immediately under water, and a cslourless mucilaginous fluid is given off copiou-ly. I have not watched the whole proces; of decay, but my impression is that the entire substance in some species would eventually pass away in a structureless glairy mass, and tberefore that nothing but a hollow impression could ever be preserved. Casts of these would be more likely to be preserved in sand or mud than mere tracks, because the substance of the weed would occupy them, and prevent them from being immediately filled with the same quality of matrix as the surrounding rock, and until what would afterwards be a line of cleavage had been produced. So far theref re from its being exceptional for fossil seaweeds to appear as casts projecting from the under surface of the overlying mud, this is likely to be the normal condition in which fossil algæe are preserved. This is apart altogether from the question whether any of the Palæozoic markings are Algæ, for, these differ so considerably from any existing forms, that in the atsence of internal structure it is quite unlikely that there will be any general agreement respecting them. The e ob ervations do not apply to the Rbodospermeæ, which scarcely enter into the question. Some simple experiments on the decay of seaweeds in fine sand under water, which any one at the seaside could make, would help to throw light on the subject. J. S. GARDNER

\section{The Weather and Sunspots}

In NAture (vol. xxvii. p. 55r) Mr. Williams ascribes the great cold of March, 1883 , at the Riviera, to the abence of sunspots. There is the less reason for ascribing this cold to sunspots, as till now much more evidence goes the other way. And may it not be contended that this evidence is in favour of warm weather, with minimum sunspots in the tropics or in summer alone. The months of November to March, 1877-78, especially February and March, were so warm over an extensive area, especially in the interior of North America and Western Siberia, that the mean temperatures were nearly without precedent, while in no extensive country of the world the temperature was much below the average.

I give some data for March, 1874 (a season with a considerable number of sunspots), at Suchum-Kale, on the east coast of the Black Sea, a place in the same latitude as Cannes, and similarly situated in respect to sea and mountains; it $i$; sheltered from cold winds, and much warmer than the surrounding country.

The observations in Russia being made at 7 a.m. and $I$ and 9 p.m., and no minimum-thermometer used, the minima cannot be strictly compared.

The mean temperatures for a long, average at Nizza (which are about the same as at Cannes) are January $47^{\circ} \cdot \mathrm{I}$, March $5 \mathrm{I}^{\circ} \cdot 8$; at Suchum-Kale, January $43^{\circ} \mathrm{O}$, March $47^{\circ} \cdot 8$, being at both about $4^{\circ}$ colder. Taking the mean of minimum and maximum as the daily mean at Cannes, and that of 7 a.m. and I and 9 p.m. as the daily mean at Suchum, we have : Coldest days of March, 1883 , at Cannes, Ioth, mean $35^{\circ} 5$, or $16^{\circ} \cdot 3$ bel ow average; I Ith, $34^{\circ} \cdot 5$, or $17^{\circ \cdot 3}$ below average ; lowest minimum on the I Ith, $24^{\circ} \cdot 1$, or $27^{\circ} .7$ below monthly, mean temperature. Coldest days of March, 1874 , at Suchum, 3 rd, $19^{\circ} 9$, or $27^{\circ} \cdot 9$ below average ; 4 th, $20^{\circ} \cdot 5,27^{\circ} \cdot 3$ below average; 5 th, $20^{\circ} \cdot 8,27^{\circ} \cup$ below average. The lowest temperature at 7 a.m. was, on the $6 \mathrm{th}, 16^{\circ} 4$, or $31^{\circ} \cdot 4$ below azerage monthly temperature. Thus it is seen that at 